\title{
KEBIJAKAN HUTANG, PROFITABLITAS, DAN MANAJEMEN ASET TERHADAP NILAI PERUSAHAAN
}

\author{
Fatimah Kurniawati Putri \\ fatimahkputri@gmail.com \\ Brady Rikumahu \\ Wiwin Aminah \\ Fakultas Ekonomi dan Bisnis, Universitas Telkom
}

diterima: 5/1/2018; direvisi: 12/3/2018; diterbitkan: 29/10/2018

\begin{abstract}
Maximizing shareholder wealth can be done by increasing the value of the company. Companies with high PBV ratios will show a high corporate value, this condition make interest for investors to invest in the company. This study aims to analyze the effect of debt policy proxied with Debt to Equity Ratio (DER), profitability proxied with Return On Equity (ROE), and asset management proxied by Total Asset Turnover (TATO) to firm value proxied by Price to Book Value, simultaneously and partially. The population is mining companies listed on BEI. Sample selection technique used is purposive sampling and obtained 30 mining companies in 2013-2016, Data analysis method is panel data regression analysis using software Eviews version 9, Based on the result of research, simultaneously DER, ROE, and TATO have significant effect to company value. Partially, DER and TATO have positive significant effect, ROE have positive but insignificant effect.
\end{abstract}

Keywords: debt policy, profitability, asset management

\begin{abstract}
Abstrak
Memaksimalkan kemakmuran pemegang saham dapat dilakukan dengan meningkatkan nilai perusahaan. Perusahaan yang memiliki rasio PBV tinggi menunjukkan nilai perusahaannya tinggi, kondisi seperti ini akan menarik investor untuk berinvestasi pada perusahaan tersebut. Penelitian ini bertujuan untuk menganalisis pengaruh kebijakan hutang yang diproksikan dengan Debt to Equity Ratio (DER), profitabilitas yang diproksikan dengan Return On Equity (ROE), dan manajemen aset yang diproksikan dengan Total Aset Turnover (TATO) terhadap nilai perusahaan yang diproksikan dengan Price to Book Value, secara simultan dan parsial. Populasi adalah perusahaan pertambangan yang terdaftar pada BEI. Teknik pemilihan sampel yang digunakan yaitu purposive sampling dan diperoleh 30 perusahaan pertambangan periode 2013-2016, Metode analisis data adalah analisis regresi data panel dengan menggunakan software Eviews versi 9, Berdasarkan hasil penelitian, secara simultan DER, ROE, dan TATO berpengaruh signifikan terhadap nilai perusahaan. Secara parsial, DER dan TATO berpengaruh positif signifikan, ROE berpengaruh positif tetapi tidak signifikan.
\end{abstract}

Kata Kunci : kebijakan hutang; profitabilitas; manajemen aset; nilai perusahaan 


\section{PENDAHULUAN}

Memaksimalkan kemakmuran pemegang saham menjadi salah satu tujuan dari perusahaan. Nilai perusahaan yang tinggi akan diikuti oleh tingginya kemakmuran pemegang saham. Nilai perusahaan dapat tergambarkan dari harga sahamnya, artinya kesejateraan pemegang saham perusahaan tersebut tinggi.

Penelitian ini, nilai perusahaan di hitung dengan menggunakan rasio Price to Book Value (PBV), sebagai perbandingan antara harga saham di pasar dengan book value. Jika rasio PBV lebih besar dari satu, berarti investor bersedia membayar lebih besar daripada nilai buku akuntansinya, dengan kemungkinan mereka berharap mendapat dividen yang nilainya tinggi, hal ini menandakan bahwa perusahaan tersebut memiliki kepercayaan yang tinggi. Perusahaan yang memiliki kemampuan dalam membagikan dividen menandakan bahwa kemampuan tersebut didukung dengan memiliki laba perusahaan yang tinggi. Oleh karena itu, investor tertarik pada perusahaan yang PBVnya tingggi. Dari hal tersebut, perusahaan yang memiliki rasio PBV tinggi akan menunjukkan nilai perusahaannya yang tinggi pula.

Peneliti luar negeri juga banyak yang melakukan penelitian mengenai nilai perusahaan, seperti Honarbkhsh dkk (2013) yang mana hasilnya kebijakan dividen bepengaruh terhadap nilai perusahaan, sedangkan peneliti Kodongo, dkk (2014) yang hasilnya menyatakan bahwa leverage secara signifikan, dan negatif, mempengaruhi profitabilitas perusahaan yang terdaftar di Kenya.

Menurut hasil penelitian Sucuahi and Cambarihan (2016), menunjukkan bahwa profitabilitas mempengaruhi nilai perusahaan dengan menggunakan Tobin's Q, secara positif dan signifikan di Bursa Efek Filipina tahun 2014.

Berbagai penelitian mengenai nilai perusahaan telah dilakukan dengan menggunakan berbagai variabel independen, antara lain kebijakan hutang suatu perusahaan, kebijakan dividen, ukuran perusahaan, tingkat profitabilitas, kinerja keuangan suatu perusahaan, kepemilikan manajerial, manajemen aset, dan lain-lain.

Kebijakan hutang diproksikan dengan Debt to Equity Ratio untuk mengukur besarnya proporsi hutang terhadap modal. Profitabilitas diproksikan dengan Return On Equity. Manajemen aset diproksikan dengan Total Asset Turnover. Sektor perusahaan pertambangan karena perusahaan pertambangan memiliki peran penting dalam pertumbuhan ekonomi negara Indonesia. Hal ini menjadi peluang dan prospek investor untuk menanamkan modalnya pada perusahaan pertambangan. Bahkan, perusahaan pertambangan memiliki ratarata PBV di atas 1, meskipun kondisi perekonomian pertambangan masih diwarnai ketidakpastian yang disebabkan berbagai faktor negatif seperti harga batubara menurun, hutang meningkat, dll.

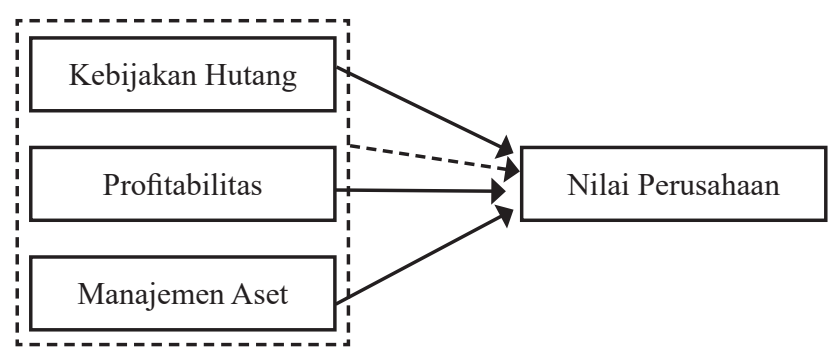

Keterangan:

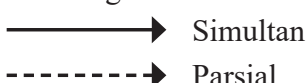

Gambar 1. Kerangka Pemikiran

Kebijakan hutang dapat diukur salah satunya dengan Debt to Equity Ratio (DER). Perusahaan yang memiliki risiko yang tinggi akan di respon negatif oleh investor karena perusahaan dianggap tidak mampu membagikan dividen yang optimal sehingga harga saham perusahaan mengalami penurunan, hal ini akan mempengaruhi nilai perusahaan secara negatif. Hal ini di dukung penelitian Mayogi (2016) dan Sumanti dan Mangantar (2015), bahwa kebijakan hutang berpengaruh negatif terhadap nilai perusahaan.

Profitabilitas memiliki pengaruh positif terhadap nilai perusahaan, karena semakin tinggi profitabilitas menunjukkan bahwa perusahaan tersebut mampu menghasilkan laba yang tinggi. (Fahmi, 2012:68). Ketika laba yang dihasilkan perusahaan semakin tinggi maka semakin baik kinerja perusahaan, artinya nilai perusahaannya tinggi sehingga investor akan tertarik untuk melakukan investasi pada perusahaan tersebut.

Hal tersebut sejalan dengan hasil penelitian yang dilakukan oleh Sumanti dan Mangantar (2015), Mayogi (2016), Putra dan Lestari (2016), serta Dewi dan Sudiartha (2017) menyatakan bahwa profitabilitas berpengaruh positif dan signifikan terhadap nilai perusahaan.

Ketika investor melihat suatu perusahaan mampu meningkatkan penjualannya dengan memanajemen asetnya dengan baik maka hal ini akan menarik perhatian investor untuk berinvestasi. Karena investor akan menilai bahwa perusahaan tersebut memiliki kemampuan yang baik dalam memanajemen asetnya untuk meningkatkan penjualannya. Sehingga manajemen aset bisa mempengaruhi peningkatan nilai perusahaan karena nilai perusahaan memiliki komponen pembentuk yakni harga saham yang terbentuk melalui permintaan investor. Hal ini didukung dengan hasil penelitian Rachman (2016) dan Rinnaya (2016) yaitu manajemen aset berpengaruh positif terhadap nilai perusahaan.

\section{METODE}

Operasionalisasi variabel ditunjukkan pada Tabel 1. Populasi adalah perusahaan pertambangan yang terdaftar di Bursa Efek Indonesia periode 2013-2016. Kriteria 
sampel pada penelitian ini adalah: (1) Secara konsisten terdaftar di Bursa Efek Indonesia (BEI) periode 20132016, (2) Secara konsisten menerbitkan Laporan Tahunan periode 2013-2016, (3) Perusahaan yang memiliki data lengkap untuk penelitian ini (Tabel 2).

Tabel 2. Kriteria Pengambilan Sampel

\begin{tabular}{clc}
\hline No & \multicolumn{1}{c}{ Kriteria Pengambilan Sampel } & Jumlah \\
\hline 1, & $\begin{array}{l}\text { Perusahaan pertambangan yang secara konsisten } \\
\text { terdaftar di Bursa Efek Indonesia (BEI) periode }\end{array}$ & 39 \\
& $\begin{array}{l}\text { 2013-2016 } \\
\text { 2, }\end{array}$ & \\
& $\begin{array}{l}\text { Perusahaan pertambangan yang tidak konsisten } \\
\text { menerbitkan Laporan Tahunan periode 2013-2016 }\end{array}$ & \\
3 & $\begin{array}{l}\text { Perusahaan yang memiliki data yang lengkap } \\
\text { untuk penelitian ini }\end{array}$ & $(6)$ \\
& $\begin{array}{l}\text { Jumlah sampel dalam penelitian } \\
\text { Jumlah data yang diolah untuk periode 4 tahun } \\
(2013-2016)\end{array}$ & 120 \\
\hline
\end{tabular}

Teknik analisis yang digunakan adalah analisis statistik deskriptif, uji korelasi dan regresi data panel.

\section{HASIL}

Pada penelitian ini variabel dependen adalah nilai perusahaan yang diproksikan dengan PBV dan variabel independen adalah Kebijakan Hutang, Profitabilitas dan Manajemen Aset. Sampel yang digunakan terdiri dari tiga puluh (30) perusahaan pertambangan yang terdaftar di Bursa Efek Indonesia tahun 2013-2016. Hasil perhitungan statistik deskriptif ditunjukkan pada Tabel 3.

Tabel 3. Statistik Deskriptif

\begin{tabular}{lrrrr}
\hline & PBV & \multicolumn{1}{c}{ DER } & \multicolumn{1}{c}{ ROE } & \multicolumn{1}{c}{ TATO } \\
\hline Rata-rata & 1,1720 & 0,5498 & 0,0948 & 0,6211 \\
Max. & 4.7700 & 4.8669 & 6,1631 & 1,8237 \\
Min. & $-1,6800$ & $-24,1183$ & $-1,6189$ & 0,0018 \\
Median & 0,9300 & 0,6982 & 0,0457 & 0,4884 \\
Std. Dev. & 1,0445 & 3,0784 & 0,6404 & 0,4890 \\
\hline
\end{tabular}

Sumber: Data yang telah diolah

Rata-rata PBV perusahaan pertambangan berada di atas 1 , artinya rata-rata perusahaan pertambangan memiliki nilai perusahaan yang tinggi. Nilai median sebesar 0,9300, menunjukkan bahwa 50\% PBV adalah di atas 0,9300 , dan sisanya di bawah 0,9300 . Adapun nilai rata-rata (mean) dari variabel dependen nilai perusahaan yang diukur dengan PBV sebesar 1,1720, sedangkan mediannya sebesar 0,9300 , artinya rata-rata lebih besar daripada median, maka data ini memiliki kurva yang miring ke kanan artinya memiliki kecenderungan data lebih besar tapi frekuensinya sedikit. Hal ini juga dapat kita lihat dari nilai standar deviasi sebesar 1,0445 , nilai standar deviasi yang kecil menunjukkan sebaran data semakin tidak bervariasi, atau adanya kesenjangan yang kecil dari nilai minimum dan maksimum. Adapun nilai maximumnya sebesar 4,7700 dan minimumnya sebesar $-1,6800$ yang artinya selisihnya 6,4500 , berarti data ini homogen atau berkelompok karena jarak maksimum dengan minimumnya dekat. Nilai maksimum ini dimiliki oleh Baramulti Suksessarana Tbk (BSSR) pada tahun 2013 sebesar 4,7700, adapun nilai minimum dimiliki oleh BUMI pada tahun 2013 sebesar -1,6800.

Rata-rata DER di bawah angka 1, artinya menunjukkan bahwa saham perusahaan lebih besar daripada pinjaman yang dimiliki perusahaan. Nilai median sebesar 0,6982, menunjukkan bahwa 50\% PBV adalah 0,6982 keatas, dan sisanya di bawah 0,6982. Adapun rata-rata (mean) dari variabel independen DER sebesar 0,5498, sedangkan mediannya sebesar 0,6982, itu artinya rata-rata lebih kecil daripada median, maka data ini memiliki kurva yang menceng ke kiri artinya memiliki kecenderungan data yang nilainya kecil lebih banyak tapi frekuensinya sedikit. Hal ini juga dapat kita lihat dari nilai standar deviasi sebesar 3,0784, nilai standar deviasi yang besar menunjukkan sebaran data semakin bervariasi, atau adanya kesenjangan yang besar dari nilai minimum dan maksimum. Adapun nilai maximumnya sebesar 4,8669 dan minimumnya sebesar $-24,1183$ yang artinya selisihnya 29,0552 , berarti data ini heterogen atau tidak berkelompok karena jarak maksimum dengan minimumnya jauh. Nilai maksimum dimiliki oleh Atlas Resources Tbk (ARII) pada tahun 2016 sebesar 4,8669. Nilai minimum dimiliki oleh Bumi Resources Tbk (BUMI) pada tahun 2013 sebesar $-24,1183$.

Rata-rata ROE mendekati angka 0,10 , menunjukkan efektivitas dan efisiensi perusahaan dalam menghasilkan pendapatan. Nilai median sebesar 0,0457, menunjukkan bahwa 50\% ROE adalah 0,0457 keatas, dan sisanya di bawah 0,0457, Adapun rata-rata (mean) dari variabel independen ROE sebesar 0,0948, sedangkan mediannya sebesar 0,0457 , itu artinya rata-rata lebih besar daripada median, maka data ini memiliki kurva yang miring ke kanan artinya memiliki kecenderungan data yang nilainya besar lebih banyak tapi frekuensinya sedikit. Hal ini juga dapat dilihat dari nilai standar deviasi sebesar 0,6404, nilai standar deviasi yang kecil menunjukkan sebaran data semakin bervariasi, atau adanya kesenjangan yang kecil dari nilai minimum dan maksimum. Adapun nilai maximumnya sebesar 6,1631 dan minimumnya sebesar $-1,6189$ yang artinya selisihnya 7,782 , berarti data ini homogen atau berkelompok karena jarak maksimum dengan minimumnya dekat. Nilai maksimum dimiliki oleh Energi Mega Persada (ENRG) pada tahun 2016 sebesar 6,1631. Nilai minimum dimiliki oleh Mitra Investindo Tbk (MITI) pada tahun 2015 sebesar -1,6189.

Rata-rata TATO 0,6211, hal ini menunjukkan bahwa perusahaan memperoleh penjualan yang nilainya 0,6211 kali dari keseluruhan aktiva yang dimilikinya. Nilai 
median sebesar 0,4884, menunjukkan bahwa 50\% TATO adalah 0,4884 keatas, dan sisanya di bawah 0,4884. Adapun rata-rata (mean) dari variabel independen TATO sebesar 0,6211, sedangkan mediannya sebesar 0,4884 , itu artinya rata-rata lebih besar daripada median, maka data ini memiliki kurva yang menceng ke kanan artinya memiliki kecenderungan data yang nilainya besar lebih banyak tapi frekuensinya sedikit. Hal ini juga dapat dilihat dari nilai standar deviasi sebesar 0,4890 . Adapun nilai maximumnya sebesar 1,8237 dan minimumnya sebesar 0,0018 yang artinya selisihnya 1,8219 berarti data ini homogen atau berkelompok karena jarak maksimum dengan minimumnya dekat. Nilai maksimum dimiliki oleh Resources Alam Indonesia Tbk (KKGI) pada tahun 2013 sebesar 1,8237, Nilai minimum dimiliki oleh Benakat Integra Tbk (BIPI) pada tahun 2016 sebesar 0,0018.

Penelitian ini menggunakan teknik analisis regresi data panel dengan menggunakan Software Eviews 9, Dalam teknik analisis ini, terdapat tiga model yang dapat dipakai, yaitu model pooling regression or common effect, model fixed effect, dan model random effect. Cara yang digunakan untuk mengetahui model yang paling cocok dilakukan pengujian dengan menggunakan Chow Test model common effect atau fixed effect, Lagrange Multiplier or Breusch-Pagan untuk model random effect atau common effect, dan Hausman Test untuk model fixed effect atau random effect.

Tabel 8. Hasil Uji Chow

\begin{tabular}{lcrl}
\hline $\begin{array}{l}\text { Redundant Fixed effects Tests } \\
\text { Equation: Untitled } \\
\text { Test cross-section fixed effects }\end{array}$ & & \\
\hline Effects Test & Statistic & d.f. & Prob. \\
\hline Cross-section F & 5,997849 & $(29,87)$ & 0,0000 \\
Cross-section Chi-square & 131,804785 & 29 & 0,0000 \\
\hline
\end{tabular}

Sumber: Hasil output Eviews versi 9

Hasil Uji Chow pada Tabel 8, menunjukkan bahwa model fixed effect lebih baik daripada model common effect.

Tabel 9. Hasil Uji Hausman

Correlated Random effects - Hausman Test
Equation: Untitled
\begin{tabular}{lrcc} 
Test cross-section random effects & & & \\
\hline Test Summary & Chi-Sq. Statistic & Chi-Sq. d.f. & Prob. \\
\hline Cross-section random & 2,165618 & 3 & 0,5388 \\
\hline
\end{tabular}

Sumber: Hasil output Eviews versi 9

Hasil Uji Hausman pada Tabel 9 menunjukan model regresi data panel yang digunakan adalah model random effect lebih baik daripada model fixed effect, serta pengujian akan dilakukan ke tahap uji signifikansi random effect.
Berdasarkan hasil (Uji Chow dan Uji Hausman) maka random effect model merupakan model yang tepat. Berdasarkan Tabel 10 dapat dirumuskan bahwa persamaan regresi data panel adalah sebagai berikut:

$\mathrm{Y}=0,805783+0,087157 \mathrm{X}_{1}+0,184255 \mathrm{X}_{2}+0,484371 \mathrm{X}_{3}+\mathrm{e}$

Dimana:

$\mathrm{Y}=$ Nilai Perusahaan $(\mathrm{PBV})$

$\mathrm{X}_{1}=$ Kebijakan Hutang (DER)

$\mathrm{X}_{2}=$ Profitabilitas (ROE)

$\mathrm{X}_{3}=$ Manajemen Aset (TATO)

$\mathrm{e}^{3}=$ Error Term

Adjusted R-Squared model sebesar 0,052970 dengan demikian, kebijakan hutang, profitabilitas, dan manajemen aset dapat menjelaskan variabel dependen yaitu nilai perusahaan yang diukur dengan PBV sebesar $5,2970 \%$, sedangkan sisanya $94,7030 \%$ dijelaskan oleh variabel lain.

Tabel 10. Hasil Pengujian Signifikansi random effect model

Dependent Variable: PBV?

Method: Pooled EGLS (Cross-section random effects)

Date: 12/16/17 Time: 08:00

Sample: 14

Included observations: 4

Cross-sections included: 30

Total pool (balanced) observations: 120

Swamy and Arora estimator of component variances

\begin{tabular}{|c|c|c|c|c|}
\hline Variable & Coefficient & Std. Error & t-Statistic & Prob. \\
\hline $\mathrm{C}$ & 0,805783 & 0,212292 & 3,795635 & 0,0002 \\
\hline DER? & 0,087157 & 0,039757 & 2,192266 & 0,0304 \\
\hline ROE? & 0,184255 & 0,167603 & 1,099353 & 0,2739 \\
\hline TATO? & 0,484371 & 0,238251 & 2,033027 & 0,0443 \\
\hline \multicolumn{5}{|c|}{ Effects Specification } \\
\hline & & & S.D. & Rho \\
\hline Cross-section & random & & 0,759078 & 0,5712 \\
\hline Idiosyncratic 1 & andom & & 0,657628 & 0,4288 \\
\hline \multicolumn{5}{|c|}{ Weighted Statistics } \\
\hline R-squared & 0,076839 & \multicolumn{2}{|c|}{ Mean dependent var } & 0,465853 \\
\hline $\begin{array}{l}\text { Adjusted } \\
\text { R-squared }\end{array}$ & 0,052964 & \multicolumn{2}{|c|}{ S.D. dependent var } & 0,673332 \\
\hline $\begin{array}{l}\text { S.E. of } \\
\text { regression }\end{array}$ & 0,655259 & \multicolumn{2}{|c|}{ Sum squared resid } & 49,80619 \\
\hline F-statistic & 3,218396 & \multirow{2}{*}{\multicolumn{2}{|c|}{ Durbin-Watson stat }} & 1,643163 \\
\hline $\begin{array}{l}\text { Prob(F- } \\
\text { statistic) }\end{array}$ & 0,025396 & & & \\
\hline \multicolumn{5}{|c|}{ Unweighted Statistics } \\
\hline R-squared & 0,121984 & \multicolumn{2}{|c|}{ Mean dependent var } & 1,172000 \\
\hline $\begin{array}{l}\text { Sum squared } \\
\text { resid }\end{array}$ & 113,9839 & \multicolumn{2}{|c|}{ Durbin-Watson stat } & 0,717993 \\
\hline
\end{tabular}


Berdasarkan Tabel 10 diperoleh bahwa nilai probabilitas adalah sebesar $0,025387<0,05$, artinya kebijakan hutang (DER), profitabilitas (ROE), dan manajemen aset (TATO) secara simultan berpengaruh terhadap nilai perusahaan yang diukur dengan PBV.

Nilai probabilitas DER adalah 0,0304 menunjukkan bahwa ROE tidak berpengaruh secara signifikan terhadap nilai perusahaan. Nilai probabilitas TATO adalah sebesar 0,0443, menunjukkan bahwa DER berpengaruh secara signifikan terhadap nilai perusahaan.

\section{PEMBAHASAN}

Tabel 4. Hasil Statistik Deskriptif PBV

\begin{tabular}{lrrrr}
\hline & 2013 & \multicolumn{1}{c}{2014} & \multicolumn{1}{c}{2015} & 2016 \\
\hline Mean & 1.4163 & 1.2653 & 0.7827 & 1.2237 \\
Maks & 4.7700 & 3.9000 & 2.4500 & 4.6600 \\
Min & -1.6800 & -0.7500 & -0.0900 & 0.2300 \\
St. Dev & 1.3553 & 1.0407 & 0.6460 & 0.9534 \\
Median & 1.0050 & 1.0100 & 0.6350 & 1.1450 \\
\hline
\end{tabular}

Sumber: Data yang telah diolah

Pada tahun 2013 bahwa rata-rata PBV berada di atas 1 , artinya rata-rata perusahaan pertambangan yang terdaftar di BEI memiliki nilai perusahaan yang tinggi. Nilai median sebesar 1,0050, menunjukkan bahwa $50 \%$ PBV adalah 1,0050 keatas, dan sisanya di bawah 1,0050. Adapun nilai rata-rata pada nilai perusahaan tahun 2013 adalah sebesar 1,4163, sedangkan mediannya sebesar 1,0050, itu artinya rata-rata lebih besar daripada median, maka data ini memiliki kurva yang menceng ke kanan artinya memiliki kecenderungan data yang nilainya besar lebih banyak tapi frekuensinya sedikit. Hal ini juga dapat kita lihat dari nilai standar deviasi sebesar 1,3553, nilai standar deviasi yang lebih kecil menunjukkan sebaran data semakin tidak bervariasi, atau adanya kesenjangan yang kecil dari nilai minimum dan maksimum. Adapun nilai maximumnya sebesar 4,7700 dan minimumnya sebesar $-1,6800$ yang artinya selisihnya 6,4500 , berarti data ini homogen atau berkelompok karena jarak maksimum dengan minimumnya dekat. Nilai tertinggi dari nilai perusahaan dimiliki oleh Baramulti Suksessarana Tbk (BSSR) tahun 2013 sebesar 4,7700. Nilai terendah dari nilai perusahaan dimiliki oleh Bumi Resources Tbk (BUMI) sebesar $-1,680$.

Pada tahun 2014 bahwa rata-rata PBV berada di atas 1 , artinya rata-rata perusahaan pertambangan yang terdaftar di BEI memiliki nilai perusahaan yang tinggi. Nilai median sebesar 1,0100, menunjukkan bahwa 50\% PBV adalah 1,0100 keatas, dan sisanya di bawah 1,0100. Adapun nilai rata-rata pada nilai perusahaan tahun 2014 adalah sebesar 1,2653 , sedangkan mediannya sebesar 1,0100 , itu artinya rata-rata lebih besar daripada median, maka data ini memiliki kurva yang menceng ke kanan artinya memiliki kecenderungan data yang nilainya besar lebih banyak tapi frekuensinya sedikit. Hal ini juga dapat kita lihat dari nilai standar deviasi sebesar 1,0407, nilai standar deviasi yang kecil menunjukkan sebaran data semakin tidak bervariasi, atau adanya kesenjangan yang kecil dari nilai minimum dan maksimum. Adapun nilai maximumnya sebesar 3,9000 dan minimumnya sebesar $-0,7500$ yang artinya selisihnya 4,6500 , berarti data ini homogen atau berkelompok karena jarak maksimum dengan minimumnya dekat. Nilai tertinggi dari nilai perusahaan dimiliki oleh Golden Energy Mines Tbk (GEMS) sebesar 3,9000. Nilai terendah dari nilai perusahaan dimiliki oleh Bumi Resources Tbk (BUMI) sebesar -0,7500.

Pada tahun 2015 bahwa rata-rata PBV berada di bawah 1 , artinya rata-rata perusahaan pertambangan yang terdaftar di BEI memiliki nilai perusahaan yang rendah. Nilai median sebesar 0,6350 menunjukkan bahwa 50\% PBV adalah 0,6350 keatas, dan sisanya di bawah 0,6350. Adapun nilai rata-rata pada nilai perusahaan tahun 2015 adalah sebesar 0,7827, sedangkan mediannya sebesar 0,6350 , itu artinya rata-rata lebih besar daripada median, maka data ini memiliki kurva yang miring ke kanan artinya memiliki kecenderungan data yang nilainya besar lebih banyak tapi frekuensinya sedikit. Hal ini juga dapat dilihat dari nilai standar deviasi sebesar 0,6460 , nilai standar deviasi yang kecil menunjukkan sebaran data semakin tidak bervariasi, atau adanya kesenjangan yang kecil dari nilai minimum dan maksimum. Adapun nilai maximumnya sebesar 2,4500 dan minimumnya sebesar $-0,0900$ yang artinya selisihnya 2,5400 , berarti data ini homogen atau berkelompok karena jarak maksimum dengan minimumnya dekat. Nilai tertinggi dari nilai perusahaan dimiliki oleh Cita Mineral Investindo Tbk (CITA) sebesar 2,4500. Nilai terendah dari nilai perusahaan dimiliki oleh Bumi Resources Tbk (BUMI) sebesar $-0,0900$.

Pada tahun 2016 bahwa rata-rata PBV berada di atas 1 , artinya rata-rata perusahaan pertambangan yang terdaftar di BEI memiliki nilai perusahaan yang tinggi. Nilai median sebesar 1,1450 menunjukkan bahwa 50\% PBV adalah 1,1450 keatas, dan sisanya di bawah 1,1450 . Adapun nilai rata-rata pada nilai tahun 2016 adalah sebesar 1,2237, sedangkan mediannya sebesar 1,1450, itu artinya rata-rata lebih besar daripada median, maka data ini memiliki kurva yang menceng ke kanan artinya memiliki kecenderungan data yang nilainya besar lebih banyak tapi frekuensinya sedikit. Hal ini juga dapat dilihat dari nilai standar deviasi sebesar 0,9534, nilai standar deviasi yang kecil menunjukkan sebaran data semakin tidak bervariasi, atau adanya kesenjangan yang kecil dari nilai minimum dan maksimum. Adapun nilai maximumnya sebesar 4,6600 dan minimumnya sebesar 0,2300 yang artinya selisihnya 4,4300 , berarti data ini homogen atau berkelompok karena jarak maksimum dengan minimumnya dekat. Nilai tertinggi dari nilai perusahaan dimiliki oleh Golden Energy Mines Tbk 
(GEMS) sebesar 4,6600. Nilai terendah dari nilai perusahaan dimiliki oleh Ratu Prabu Energi Tbk (ARTI) sebesar 0,2300.

Jika DER berada di bawah 1, artinya menunjukkan bahwa saham perusahaan lebih besar daripada pinjaman yang dimiliki perusahaan. Oleh karena itu, investor harus teliti dalam menganalisis DER karena jika total kewajibannya lebih besar daripada ekuitas maka harus diamati lebih lanjut kewajiban manakah yang lebih besar, apakah kewajiban lancar atau kewajiban jangka panjang. Jika jumlah hutang lancarnya lebih besar, hal ini masih dapat diterima karena besarnya hutang sering disebabkan oleh hutang operasi yang bersifat jangka pendek. Jika hutang jangka Panjang lebih besar, maka di khawatirkan perusahaan tersebut akan mengalami risiko gangguan likuiditas dimasa yang akan datang. Kecuali jika laba perusahaan digunakan untuk memenuhi hutang.

Perusahaan yang memiliki DER lebih dari 1, maka dapat mempengaruhi risiko pertumbuhan kinerja perusahaan, dan harga sahamnya. Oleh karena itu sebagian investor tidak tertarik berinvestasi pada perusahaan yang mempunyai DER lebih dari 2.

Tabel 5. Hasil Statistik Deskriptif DER

\begin{tabular}{lrrrr}
\hline & \multicolumn{1}{c}{2013} & \multicolumn{1}{c}{2014} & \multicolumn{1}{c}{2015} & \multicolumn{1}{c}{2016} \\
\hline Mean & 0.1815 & 1.2215 & 0.9347 & 0.4363 \\
Maks & 3.8795 & 19.1593 & 3.2868 & 4.8669 \\
Min & -24.1183 & -9.8679 & -2.1685 & -15.8173 \\
St. Dev & 4.6735 & 4.0113 & 1.0621 & 3.3060 \\
Median & 0.6734 & 0.7023 & 0.7275 & 0.6914 \\
\hline
\end{tabular}

Sumber: Data yang telah diolah

Pada tahun 2013 rata-rata DER berada di bawah 1 , artinya perusahaan memiliki hutang yang lebih rendah daripada modal yang dimilikinya. Nilai median sebesar 0,6734 menunjukkan bahwa 50\% DER adalah 0,6734 keatas, dan sisanya di bawah 0,6734. Adapun nilai rata-rata Debt to Equity tahun 2013 sebesar 0,1815, sedangkan mediannya sebesar 0,6734, itu artinya rata-rata lebih kecil daripada median, maka data ini memiliki kurva yang menceng ke kiri artinya memiliki kecenderungan data yang nilainya kecil lebih banyak tapi frekuensinya sedikit. Hal ini juga dapat kita lihat dari nilai standar deviasi sebesar 4,6735, nilai standar deviasi yang besar menunjukkan sebaran data semakin bervariasi, atau adanya kesenjangan yang besar dari nilai minimum dan maksimum. Adapun nilai maximumnya sebesar sebesar 3,8795 dan minimumnya sebesar -24,1183 yang artinya selisihnya 27,9978, berarti data ini heterogen atau tidak berkelompok karena jarak maksimum dengan minimumnya jauh. Nilai tertinggi DER dimiliki oleh Radiant Utama Interinsco Tbk (RUIS) sebesar 3,8795, Nilai terendah DER dimiliki oleh Bumi Resources Tbk (BUMI) sebesar $-24,1183$.
Pada tahun 2014 rata-rata DER berada di atas 1, artinya perusahaan memiliki hutang yang lebih tinggi daripada modal yang dimilikinya. Nilai median sebesar 0,7023, menunjukkan bahwa 50\% DER adalah 0,7023 keatas, dan sisanya di bawah 0,7023. Adapun, nilai rata-rata Debt to Equity tahun 2014 sebesar 1,2215, sedangkan mediannya sebesar 0,7023, itu artinya rata-rata lebih besar daripada median, maka data ini memiliki kurva yang menceng ke kanan artinya memiliki kecenderungan data yang nilainya besar lebih banyak tapi frekuensinya sedikit. Hal ini juga dapat kita lihat dari nilai standar deviasi sebesar 4,0113, nilai standar deviasi yang besar menunjukkan sebaran data semakin bervariasi, atau adanya kesenjangan yang besar dari nilai minimum dan maksimum. Adapun nilai maximumnya sebesar sebesar 19,1593 dan minimumnya sebesar -9,8679 yang artinya selisihnya 29,0272, berarti data ini heterogen atau tidak berkelompok karena jarak maksimum dengan minimumnya jauh. Nilai tertinggi DER dimiliki oleh Benakat Integra Tbk (BIPI) sebesar 19,1593. Nilai terendah DER dimiliki oleh Bumi Resources Tbk (BUMI) sebesar -9,8679.

Pada tahun 2015 rata-rata DER berada di bawah 1 , artinya perusahaan memilik hutang yang lebih rendah daripada modal yang dimilikinya. Nilai median sebesar 0,7275, menunjukkan bahwa 50\% DER adalah 0,7275 keatas, dan sisanya di bawah 0,7275 . Adapun nilai rata-rata DER tahun 2015 sebesar 0,9347, sedangkan mediannya sebesar 0,7275 , itu artinya rata-rata lebih besar daripada median, maka data ini memiliki kurva yang menceng ke kanan artinya memiliki kecenderungan data yang nilainya besar lebih banyak tapi frekuensinya sedikit. Hal ini juga dapat kita lihat dari nilai standar deviasi sebesar 1,0621, nilai standar deviasi yang kecil menunjukkan sebaran data semakin tidak bervariasi, atau adanya kesenjangan yang kecil dari nilai minimum dan maksimum. Adapun nilai maximumnya sebesar sebesar 3,2868 dan minimumnya sebesar -2,1685 yang artinya selisihnya 5,4553 , berarti data ini homogen atau berkelompok karena jarak maksimum dengan minimumnya dekat. Nilai tertinggi DER dimiliki oleh Atlas Resources Tbk (ARII) sebesar 3,2868. Nilai terendah DER dimiliki oleh Bumi Resources Tbk (BUMI) sebesar -2,1685.

Pada tahun 2016 rata-rata DER berada di bawah 1, artinya perusahaan memiliki hutang yang lebih rendah daripada modal yang dimilikinya. Nilai median sebesar 4,8669, menunjukkan bahwa 50\% DER adalah 4,8669 keatas, dan sisanya di bawah 4,8669. Adapun nilai rata-rata DER tahun 2016 sebesar 0,4363, sedangkan mediannya sebesar 4,8669, itu artinya rata-rata lebih kecil daripada median, maka data ini memiliki kurva yang menceng ke kiri artinya memiliki kecenderungan data yang nilainya kecil lebih banyak tapi frekuensinya sedikit. Hal ini juga dapat kita lihat dari nilai standar deviasi sebesar 3,3060, nilai standar deviasi yang besar menunjukkan sebaran data semakin bervariasi, atau 
adanya kesenjangan yang besar dari nilai minimum dan maksimum. Adapun nilai maximumnya sebesar sebesar 4,8669 dan minimumnya sebesar - 15,8173 yang artinya selisihnya 20,6842 , berarti data ini heterogen atau tidak berkelompok karena jarak maksimum dengan minimumnya jauh. Nilai tertinggi DER dimiliki oleh Atlas Resources Tbk (ARII) sebesar 4,8669. Nilai terendah DER dimiliki oleh Energi Mega Persada (ENRG) sebesar -15,8173.

Tabel 6. Hasil Statistik Deskriptif ROE

\begin{tabular}{lcrrr}
\hline & 2013 & \multicolumn{1}{l}{2014} & \multicolumn{1}{c}{2015} & \multicolumn{1}{c}{2016} \\
\hline Mean & 0.1546 & 0.0811 & 0.2419 & 0.1921 \\
Maks & 2.1789 & 0.6356 & 7.0960 & 6.1631 \\
Min & -0.2330 & -0.2767 & -0.7807 & -0.5804 \\
St. Dev & 0.4015 & 0.1626 & 1.3175 & 1.1455 \\
Median & 0.0803 & 0.0549 & 0.0147 & 0.0482 \\
\hline
\end{tabular}

Sumber: Data yang telah diolah

Pada tahun 2013 rata-rata hasil ROE 0,1546. Nilai median sebesar 0,0803 , menunjukkan bahwa $50 \%$ ROE adalah 0,0803 keatas, dan sisanya di bawah 0,0803. Adapun nilai rata-rata ROE tahun 2013 sebesar 0,1546, sedangkan mediannya sebesar 0,0803 , itu artinya rata-rata lebih besar daripada median, maka data ini memiliki kurva yang menceng ke kanan artinya memiliki kecenderungan data yang nilainya besar lebih banyak tapi frekuensinya sedikit. Hal ini juga dapat dilihat dari nilai standar deviasi sebesar 0,4015, menunjukkan sebaran data semakin tidak bervariasi, atau adanya kesenjangan yang kecil dari nilai minimum dan maksimum. Adapun nilai maximumnya sebesar sebesar 2,1789 dan minimumnya sebesar - 0,2330 yang artinya selisihnya 2,4119 , berarti data ini homogen atau berkelompok karena jarak maksimum dengan minimumnya dekat. Nilai tertinggi ROE dimiliki oleh Bumi Resources Tbk (BUMI) sebesar 2,1789. Nilai terendah ROE dimiliki oleh Darma Henwa Tbk (DEWA) sebesar $-0,2330$.

Pada tahun 2014 rata-rata hasil ROE 0,0811. Nilai median sebesar 0,0549 , menunjukkan bahwa 50\% ROE adalah 0,0549 keatas, dan sisanya di bawah 0,0549 . Adapun nilai rata-rata ROE tahun 2014 sebesar 0,0811 , sedangkan mediannya sebesar 0,0549 itu artinya rata-rata lebih besar daripada median, maka data ini memiliki kurva yang menceng ke kanan artinya memiliki kecenderungan data yang nilainya besar lebih banyak tapi frekuensinya sedikit. Nilai standar deviasi sebesar 0,1626 semakin tidak bervariasi, atau adanya kesenjangan yang kecil dari nilai minimum dan maksimum. Adapun nilai maximumnya sebesar sebesar 0,6356 dan minimumnya sebesar $-0,2767$ yang artinya selisihnya 0,9123 berarti data ini homogen atau berkelompok karena jarak maksimum dengan minimumnya dekat. Nilai tertinggi ROE dimiliki oleh Bumi Resources Tbk (BUMI) sebesar 0,6356. Nilai terendah ROE dimiliki oleh Cakra Mineral Tbk (CKRA) sebesar $-0,2767$.

Pada tahun 2015 rata-rata hasil ROE 0,2419. Nilai median sebesar 0,0095, menunjukkan bahwa 50\% ROE adalah 0,0095 keatas, dan sisanya di bawah 0,0095 . Adapun nilai rata-rata ROE tahun 2015 sebesar $-0,0486$, sedangkan mediannya sebesar 0,0095 itu artinya rata-rata lebih besar daripada median, maka data ini memiliki kurva yang menceng ke kanan artinya memiliki kecenderungan data yang nilainya besar lebih banyak tapi frekuensinya sedikit. Hal ini juga dapat kita lihat dari nilai standar deviasi sebesar 0,3845 nilai standar deviasi yang kecil menunjukkan sebaran data semakin tidak bervariasi, atau adanya kesenjangan yang kecil dari nilai minimum dan maksimum. Adapun nilai maximumnya sebesar sebesar 0,7532 dan minimumnya sebesar $-1,6189$ yang artinya selisihnya 2,3721, berarti data ini homogen atau berkelompok karena jarak maksimum dengan minimumnya dekat. Nilai tertinggi ROE dimiliki oleh Bumi Resources Tbk (BUMI) sebesar 0,7523. Nilai terendah ROE dimiliki oleh Mitra Investindo Tbk (MITI) sebesar -1,6189.

Pada tahun 2016 rata-rata hasil ROE 0,1921. Nilai median sebesar 0,0482 , menunjukkan bahwa $50 \%$ ROE adalah 0,0482 keatas, dan sisanya di bawah 0,0482. Adapun nilai rata-rata ROE tahun 2016 sebesar 0,1921, sedangkan mediannya sebesar 0,0482 , itu artinya rata-rata lebih besar daripada median, maka data ini memiliki kurva yang menceng ke kanan artinya memiliki kecenderungan data yang nilainya besar lebih banyak tapi frekuensinya sedikit. Hal ini juga dapat kita lihat dari nilai standar deviasi sebesar 1,1455, nilai standar deviasi yang besar menunjukkan sebaran data semakin bervariasi, atau adanya kesenjangan yang besar dari nilai minimum dan maksimum. Adapun nilai maximumnya sebesar sebesar 6,1631 dan minimumnya sebesar $-0,5804$ yang artinya selisihnya 6,7435 , berarti data ini heterogen atau tidak berkelompok karena jarak maksimum dengan minimumnya jauh. Nilai tertinggi ROE dimiliki oleh Energi Mega Persada (ENRG) sebesar 6,1631. Nilai terendah ROE dimiliki oleh Benakat Integra Tbk (BIPI) sebesar -0,5804.

Tabel 7. Hasil Statistik Deskriptif TATO

\begin{tabular}{lcccc}
\hline & 2013 & 2014 & 2015 & 2016 \\
\hline Mean & 0.7611 & 0.6787 & 0.5447 & 0.4998 \\
Maks & 1.8237 & 1.6632 & 1.4897 & 1.3437 \\
Min & 0.0387 & 0.0296 & 0.0050 & 0.0018 \\
St. Dev & 0.5142 & 0.4856 & 0.4901 & 0.4424 \\
Median & 0.6571 & 0.4927 & 0.3880 & 0.4177 \\
\hline
\end{tabular}

Sumber: Data yang telah diolah

Pada tahun 2013 median sebesar 0,6571, menunjukkan bahwa 50\% TATO adalah 0,6571 keatas, dan sisanya di bawah 0,6571 . Adapun nilai rata-rata TATO tahun 2013 sebesar 0,7611, sedangkan mediannya 
sebesar 0,6571 itu artinya rata-rata lebih besar daripada median, maka data ini memiliki kurva yang menceng ke kanan artinya memiliki kecenderungan data yang nilainya besar lebih banyak tapi frekuensinya sedikit. Hal ini juga dapat kita lihat dari nilai standar deviasi sebesar 0,5142. Adapun nilai maximumnya sebesar sebesar 1,8237 dan minimumnya sebesar 0,0387 yang artinya selisihnya 1,7850 , berarti data ini homogen atau berkelompok karena jarak maksimum dengan minimumnya dekat. Nilai tertinggi TATO dimiliki oleh Resource Alam Indonesia Tbk (KKGI) sebesar 1,8237. Nilai terendah TATO dimiliki oleh Cakra Mineral Tbk (CKRA) sebesar 0,0387.

Pada tahun 2014 median sebesar 0,4927 , menunjukkan bahwa 50\% TATO adalah 0,4927 keatas, dan sisanya di bawah 0,4927 . Adapun nilai rata-rata TATO tahun 2014 sebesar 0,6787 , sedangkan mediannya sebesar 0,4927 itu artinya rata-rata lebih besar daripada median, maka data ini memiliki kurva yang menceng ke kanan artinya memiliki kecenderungan data yang nilainya besar lebih banyak tapi frekuensinya sedikit. Hal ini juga dapat dilihat dari nilai standar deviasi sebesar 0,4856. Adapun nilai maximumnya sebesar sebesar 1,6632 dan minimumnya sebesar 0,0296 yang artinya selisihnya 1,6336 , berarti data ini homogen atau berkelompok karena jarak maksimum dengan minimumnya dekat. Nilai tertinggi TATO dimiliki oleh Toba Bara Sejahtera Tbk (TOBA) sebesar 1,6632. Nilai terendah TATO dimiliki oleh Cakra Mineral Tbk (CKRA) sebesar 0,0296.

Pada tahun 2015 median sebesar 0,3880, menunjukkan bahwa 50\% TATO adalah 0,3880 keatas, dan sisanya di bawah 0,3880 . Adapun nilai rata-rata TATO tahun 2015 sebesar 0,5447 , sedangkan mediannya sebesar 0,3880, itu artinya rata-rata lebih besar daripada median, maka data ini memiliki kurva yang menceng ke kanan artinya memiliki kecenderungan data yang nilainya besar lebih banyak tapi frekuensinya sedikit. Hal ini juga dapat dilihat dari nilai standar deviasi sebesar 0,4901. Adapun nilai maximumnya sebesar sebesar 1,4897 dan minimumnya sebesar 0,0050 yang artinya selisihnya 1,4847 , berarti data ini homogen atau berkelompok karena jarak maksimum dengan minimumnya dekat. Nilai tertinggi TATO dimiliki oleh Baramulti Suksessarana Tbk (BSSR) sebesar 1,4897. Nilai terendah TATO dimiliki oleh Cita Mineral Investindo Tbk (CITA) sebesar 0,0050.

Pada tahun 2016 median sebesar 0,4177, menunjukkan bahwa 50\% TATO adalah 0,4177 keatas, dan sisanya di bawah 0,4177 . Adapun nilai rata-rata TATO tahun 2016 sebesar 0,4998 , sedangkan mediannya sebesar 0,4177 , itu artinya rata-rata lebih besar daripada median, maka data ini memiliki kurva yang menceng ke kanan artinya memiliki kecenderungan data yang nilainya besar lebih banyak tapi frekuensinya sedikit. Hal ini juga dapat dilihat dari nilai standar deviasi sebesar 0,4424. Adapun nilai maximumnya sebesar sebesar 1,3437 dan minimumnya sebesar 0,0018 yang artinya selisihnya 1,3419 , berarti data ini homogen atau berkelompok karena jarak maksimum dengan minimumnya dekat. Nilai tertinggi TATO dimiliki oleh Radiant Utama Interinsco Tbk (RUIS) sebesar 1,3437. Nilai terendah TATO dimiliki oleh Benakat Integra Tbk (BIPI) sebesar 0,0018.

Koefisien regresi pada DER 0,087157 yang memiliki nilai positif menunjukkan hubungan positif dengan nilai perusahaan yang diukur dengan PBV, artinya semakin tinggi DER menyebabkan nilai perusahaan meningkat. Hal ini tidak sesuai dengan hipotesis dari penulis.

Dapat dilihat dari hasil statistika deskriptif kebijakan hutang dengan nilai perusahaan, kedua variabel tersebut memiliki persebaran arah yang positif, karena dari 30 perusahaan pertambangan terdapat 16 perusahaan yang memiliki persebaran data sejalan yaitu data yang sama-sama di atas rata-rata dan atau sama-sama di bawah rata-rata. Hal ini dapat memicu terjadinya hasil penemuan bahwa kebijakan hutang berpengaruh positif terhadap nilai perusahaan.

Hasil penelitian ini sejalan dengan Ulya (2014) dan Jefriansyah (2015) yang menyatakan bahwa kebijakan hutang berpengaruh positif signifikan terhadap nilai perusahaan. DER yang berpengaruh positif signifikan dikarenakan ketika DER yang tinggi dapat memberikan nilai terhadap perusahaan, semakin tinggi DER dapat digunakan untuk meningkatkan produksi perusahaan yang akhirnya bisa meningkatkan laba perusahaan. Peningkatan Leverage dapat menunjukkan berita baik jika manajemen mengolah pinjaman dengan baik sehingga menghasilkan laba yang tinggi yang menyebabkan peningkatkan nilai perusahaan.

Kebijakan hutang yang tinggi menunjukkan bahwa perusahaan cenderung menggunakan hutang sebagai struktur permodalan mereka, sehingga apabila perusahaan mendapatkan laba, laba tersebut akan digunakan untuk membayar hutang mereka (Vaeza, 2015). Sedangkan, menurut Brigham \& Houston (2011) dalam Solikahan et al. (2013), perusahaan yang menggunakan hutang dalam membiayai investasi diharapkan dapat meningkatkan nilai perusahaan.

Koefisien regresi ROE 0,184255 yang memiliki nilai positif menunjukkan hubungan positif dengan nilai perusahaan yang diukur dengan PBV, artinya semakin tinggi tingkat ROE perusahaan maka nilai perusahaan akan meningkat. Perusahaan yang semakin baik rasio profitabilitas maka semakin baik menggambarkan kemampuan tingginya perolehan keuntungan perusahaan (Fahmi, 2012:68); (Dewi dan Sudiartha, 2017); (Sambora et al, 2014).

Dapat dilihat dari hasil statistika deskriptif profitabilitas dengan nilai perusahaan, kedua variabel tersebut memiliki persebaran arah yang positif, karena dari 30 perusahaan pertambangan terdapat 22 perusahaan yang memiliki persebaran data sejalan yaitu data yang sama-sama di atas rata-rata dan atau sama-sama di bawah rata-rata. 
Pengaruh profitabilitas terhadap nilai perusahaan tidak signifikan. Artinya berapapun banyaknya profitabilitas yang digunakan perusahaan tidak akan mempengaruhi tingkat nilai perusahaan. Selain itu, tingkat ROE suatu perusahaan belum tentu memberikan nilai tambah yang besar pula terhadap investor, karena nilai pengembalian investasi tergantung pada besar modal yang diinvestasikan oleh para investor.

$\mathrm{Hal}$ tersebut tidak sejalan dengan hasil penelitian yang dilakukan oleh peneliti luar negeri bernama Chen, L. J. and Chen, S. Y. (2011) juga menyatakan hasilnya Profitability terhadap Firm Value berpengaruh positif pada perusahaan. Sumanti dan Mangantar (2015), Mayogi (2016), Putra dan Lestari (2016), serta Dewi dan Sudiartha (2017) menyatakan bahwa profitabilitas berpengaruh positif dan signifikan terhadap nilai perusahaan.

Koefisien regresi TATO sebesar 0,484371 yang memiliki nilai positif menunjukkan hubungan positif dengan nilai perusahaan yang diukur dengan PBV, artinya semakin tinggi tingkat TATO perusahaan maka nilai perusahaan akan meningkat.

Dapat dilihat dari hasil statistika deskriptif manajemen aset dengan nilai perusahaan, kedua variabel tersebut memiliki persebaran arah yang positif, karena dari 30 perusahaan pertambangan terdapat 22 perusahaan yang memiliki persebaran data sejalan yaitu data yang sama-sama di atas rata-rata dan atau sama-sama di bawah rata-rata. Hal ini dapat memicu terjadinya hasil penemuan bahwa manajemen aset berpengaruh positif terhadap nilai perusahaan.

Hal ini didukung dengan hasil penelitian Rachman (2016) dan Rinnaya (2016) yaitu manajemen aset berpengaruh positif terhadap nilai perusahaan. Artinya semakin besar TATO perusahaan maka semakin efektif penggunaan aktiva perusahaan dalam menunjang kegiatan penjualan. Ketika investor melihat suatu perusahaan mampu meningkatkan penjualannya dengan memanajemen asetnya dengan baik maka hal ini akan menarik perhatian investor untuk berinvestasi. Sehingga manajemen aset bisa mempengaruhi peningkatan nilai perusahaan karena nilai perusahaan memiliki komponen pembentuk yakni harga saham yang terbentuk melalui permintaan investor.

\section{KESIMPULAN}

Pengujian secara simultan kebijakan hutang, profitabilitas, dan manajemen aset secara simultan berpengaruh signifikan terhadap nilai perusahaan pada perusahaan pertambangan yang terdaftar di Bursa Efek Indonesia periode 2013-2016. Pengujian secara parsial adalah sebagai berikut: (1) Kebijakan hutang berpengaruh negatif signifikan; (2) Profitabilitas berpengaruh positif tidak signifikan, dan (3) Manajemen Aset berpengaruh signifikan terhadap nilai perusahaan.

\section{DAFTAR PUSTAKA}

Brigham, E. F., \& Houston, J. F. 2001, In Manajemen Keuangan. Jakarta: Erlangga.

Chen, L.-J., \& Chen, S.-Y. 2011. The Influence of Profitability on Firm Value with Capital Structure as The Mediator and Firm Size and Industry as Moderators. Investment Management and Financial Innovations, Volume 8, Issue 3, 2011.

Dewi, D. A., \& Sudiartha, G. M. 2017, Pengaruh Profitabilitas, Ukuran Perusahaan, dan Pertumbuhan Aset terhadap Struktur Modal dan Nilai Perusahaan. E-Jurnal Manajemen Unud, Vol. 6, No. 4, 2017: 2222-2252, ISSN : 2302-8912,

Fahmi, I. 2012, Analisis Laporan Keuangan. Bandung: ALFABETA.

Hery, S. M. 2015, In Analisis Laporan Keuangan (p. 189). Jakarta: Center for Academic Publishing Service.

Honarbkhsh, S., Birjandi, H., \& Birjandi, M. 2013. The Effects of Dividend Policy on Market Value on Companies Listed in Tehran Stock Exchange. International Review of Management and Business Research, vol. 2, Issue. 1.

Jefriansyah. 2015, Pengaruh Kebijakan Hutang dan Manajemen Laba terhadap Nilai Perusahaan. Skripsi Universitas Negeri Padang.

Kodongo, O., Mokoaleli-Mokoteli, T., \& Maina, L. N. 2014. Capital Structure, Profitability and Firm Value: Panel Evidence of Listed Firm in Kenya. University of the Witwatersrand, SSRN : 2465422.

Mayogi, D. G. 2016, Pengaruh Profitabilitas, Kebijakan Dividen, dan Kebijakan Utang terhadap Nilai Perusahaan.

Pakpahan, R. 2010, Pengaruh Faktor-Faktor Fundamental Perusahaan dan Kebijakan Deviden terhadap Nilai Perusahaan (Studi Kasus pada Perusahaan Manufaktur Periode 2003-2007). Jurnal Ekonomi, Keuangan Perbankan dan Akuntansi Vol. 2, No, 2 November 2010, 211-277,

Putra, A. N., \& Lestari, P. V. 2016, Pengaruh Kebijakan Dividen, Likuiditas, Profitabilitas dan Ukuran Perusahaan terhadap Nilai Perusahaan. E-Jurnal Manajemen Unud, Vol. 5, No.7, 2016: 4044 - 4070,

Rachman, N. A. 2016, Faktor-Faktor yang Mempengaruhi Nilai Perusahaan pada Sektor Industri Food and Beverages yang Terdaftar di Bursa Efek Indonesia (BEI) pada Tahun 2011-2015, Skripsi Jurusan Pendidikan Ekonomi, Universitas Negeri Yogyakarta.

Rinnaya, I. Y. 2016, Journal of Accounting, Volume 2 No.2 Maret 2016, Pengaruh Profitabilitas, Rasio Aktivitas, Keputusan Pendanaan, dan Keputusan Investasi Terhadap Nilai Perusahaan.

Sambora, M. N., Handayani, S. R., \& Rahayu, S. M. 2014. Pengaruh Leverage dan profitabilitas 
Terhadap Nilai Perusahaan. Jurnal Administrasi Bisnis Vol 8 No.1 Februari 2014.

Solikahan, E. Z. 2013. Pengaruh Leverage dan Investasi terhadap Nilai Perusahaan (Studi pada Perusahaan Makanan dan Minuman di Bursa Efek Indonesia). Jurnal Aplikasi Manajemen. Vol. 11, No. 3, September 2013.

Sucuahi, W., \& Cambarihan, J. M. 2016. Influence of Profitability to the Firm Value of Diversified Companies in the Philippines. Accounting and Finance Research, Sciedu Press Vol. 5, No. 2; 2016, ISSN 1927-5986 E-ISSN 1927-5994.

Sumanti, J. C., \& Mangantar, M. 2015, Analisis
Kepemilikan Manajerial, Kebijakan Hutang dan Profitabilitas terhadap Kebijakan Dividen dan Nilai Perusahaan pada Perusahaan Manufaktur yang Terdaftar di BEI.

Ulya, H. 2014. Analisis Pengaruh Kebijakan Hutang, Kebijakan Dividen, Profitabilitas, kinerja Perusahaan dan Keputusan Investasi Terhadap Nilai Perusahaan pada Perusahaan Manufaktur yang Terdaftar di BEI Tahun 2009-2011, Jurnal Universitas Dian Nuswantoro Semarang.

Vaeza, N. D. 2015, Pengaruh Ukuran Perusahaan, Profitabilitas, Leverage dan Kebijakan Dividen terhadap Nilai Perusahaan.

Tabel 1. Operasionalisasi Variabel

\begin{tabular}{|c|c|c|c|c|}
\hline Variabel & Definisi Variabel & Skala & \multicolumn{2}{|c|}{ Indikator } \\
\hline \multicolumn{5}{|c|}{ Variabel Independen } \\
\hline \multirow{2}{*}{$\begin{array}{l}\text { Kebijakan } \\
\text { Hutang }\end{array}$} & \multirow{2}{*}{$\begin{array}{l}\text { Kebijakan hutang merupakan kemampuan perusahaan } \\
\text { dalam memenuhi seluruh kewajibannya (Hery, 2015:167). }\end{array}$} & \multirow[t]{2}{*}{ Rasio } & \multirow{2}{*}{$\mathrm{DER}=-$} & Total Hutang \\
\hline & & & & Total Modal Sendiri \\
\hline \multirow[t]{2}{*}{ Profitabilitas } & \multirow{2}{*}{$\begin{array}{l}\text { Rasio profitabilitas merupakan rasio yang menggambarkan } \\
\text { kemampuan perusahaan dalam menghasilkan laba (Hery, } \\
\text { 2015:168). }\end{array}$} & \multirow[t]{2}{*}{ Rasio } & \multicolumn{2}{|c|}{ Laba Bersih } \\
\hline & & & \multicolumn{2}{|c|}{ Total Ekuitas } \\
\hline \multirow{2}{*}{$\begin{array}{l}\text { Manajemen } \\
\text { Aset }\end{array}$} & \multirow{2}{*}{$\begin{array}{l}\text { Rasio manajemen aset adalah rasio yang mengukur } \\
\text { seberapa efektif perusahaan mengelola asetnya (Brigham } \\
\text { \& Houston , 2010:136). }\end{array}$} & \multirow[t]{2}{*}{ Rasio } & \multirow{2}{*}{ Perputaran total aset $=$} & Penjualan \\
\hline & & & & Total Aset \\
\hline \multicolumn{5}{|c|}{ Variabel Dependen } \\
\hline \multirow{2}{*}{$\begin{array}{c}\text { Nilai } \\
\text { Perusahaan }\end{array}$} & \multirow{2}{*}{$\begin{array}{l}\text { Nilai perusahaan merupakan persepsi investor terhadap } \\
\text { tingkat keberhasilan perusahaan (Pakpahan, 2010). }\end{array}$} & \multirow[t]{2}{*}{ Rasio } & \multirow{2}{*}{$\mathrm{PBV}=\frac{\text { Harga pasar per }}{\text { Nilai buku per }}$} & bar saham biasa \\
\hline & & & & bar saham biasa \\
\hline
\end{tabular}

